\title{
Biologic effect of ionizing radiation
}

\begin{abstract}
lonizing radiation is a well-known risk factor for developing benign and malignant diseases including different types of cancer. Despite its proven deleterious effects there is still a high unawareness about its importance. There is no a complete adherence to the use of protective tools for avoiding radiation exposure in the cath lab, especially in head and eye protection. New theories have been discovered which help to explain different ways through ionizing radiation makes damage in the cell and molecular level in the exposed organisms. The present review article is intended to discuss the mechanisms of biological damage and main diseases related to ionizing radiation exposure.
\end{abstract}

Keywords: lonizing radiation - Cancer - Interventional cardiology - Bystander effect - DNA damage

\section{Introduction}

Radiation in interventional cardiology has had during the last years. There is a concern especially in developing countries, where the research about this topic is minimum or even nonexistent; the education to fellows in electrophysiology and interventional cardiology about radiation protection is poor, the regulation of the occupational exposure is not well controlled and the adherence of medical centers and professionals to radiation protection measures is flexible.

A trial performed in Lithuania [1] reported the following findings: thyroid protectors were used about $93.5 \%$ of the cases, bulkhead protector in $83,9 \%$ and the leaded glasses just about $35.5 \%$ Showing, as mentioned above, the low awareness of the professionals performing these kind of procedures and the lack of radioprotection education in universities and medical practice centers. Furthermore, there is lack of government control, regulatory instructions and health instructions forcing health professionals to wear protection during all of the procedures. A big part of the catheterization laboratories have never worn leaded protector hat to avoid brain radiation.

One of the possible explanations about the lack of awareness could be the poor knowledge in this important topic, the discomfort of wearing the protectors and the prolonged time to develop any kind of cancer which gives a sensation of tranquility and relief to the radiation exposure, which is invisible to the human perception, is neither palpable nor perceptible. In the article of Roguin et al. [2] the required time receiving radiation in order to develop brain tumors is among 12 to 32 years (in average 22 years).

\section{Key concepts}

In order to discuss about the role of ionizing radiation in the biologic organism two ways of damage have to be mentioned: stochastic and deterministic effects.

Stochastic effects (probabilistic) are those that can appear but not necessarily occur, they have certain probability to occur and the common examples are cancer and genetic mutations.

Deterministic effects are dose-related accumulative effects. When a determined level of radiation is reached, either accumulative dose or single dose, certain alterations related with the dose can appear. For example, for developing opacities in the crystalline it is necessary to receive single dose of $2 \mathrm{~Gy}$ or fractioned doses of $5 \mathrm{~Gy}(11)$.

\section{Biological Damage due to lonizing Radiation \\ Ionizing radiation may produce DNA}

Julio Cesar Rodriguez Goyes*, Nicolas Jaramillo Gomez, Valentina Jaramillo Restrepo, Simon Gaviria, Andrea Hincapie, Eduardo Arias

Clinica Las Americas, Unidad de Cuidados Intensivos, Diagonal 75B No. 2A-80/140, Medellin (Antioquia), Colombia

*Author for correspondence: Tel.: (57)-3166973475

Email: Julliusc@yahoo.com.mx Received date: July 01, 2018

Accepted date: October 11, 2018

Published date: October 18, 2018 
damage, cell death and organelle damage, particularly to the mitochondria, which causes alterations in the cellular immunity response. Exposure to ionizing radiation is also associated to cytokine and chemokine liberation, rise in the levels of free radicals, tumor suppressor gene inhibition and increase in oncogene activation [3].

It produces single-strand and double-strand DNA damage. Most of these lesions to single-stranded DNA may be repaired, however, damage to double-stranded DNA may cause cell death. When damaged, nonrepaired DNA accumulates and generates deletions, mutations and chromosomal alterations, which eventually lead to cell death. DNA damage may be classified as direct, which corresponds mainly to the damage produced by ionizing radiation, and indirect damage, which is due to substances, such as oxygen reactive forms, which are generated by the exposure to ionizing radiation [3]. Simultaneously, DNA damage generates oxidized DNA forms, which activates the inflammatory cascade [4].

Mitochondrial DNA damage generates more oxidation and liberation into the cytosol. Oxidized mitochondrial DNA binds to the inflammasome (NLRP3). The inflammasome supports the formation of IL-1B and IL-18 [5].

Inflammatory cytokines and growth factors generated by the irradiated cells lead to multiple inflammatory cascades which stimulate the formation of oxygen reactive substances and nitric oxide through the activation of enzymes such ad NADPH oxidase, inducible nitric oxide synthetase and cyclooxygenase 2 (COX2) [6].

The recognition of injurious molecules such as DAMP (damage associated molecular pattern), is done through the TLR (toll-like receptors) in inflammatory cells. This interaction promotes inflammatory cascades, NF-KB transcription and protein activators (AP-1). The levels of NF-KB are also increased through the interaction of other TLR (TLR 2,4,5,9) with molecules such as HMGB1 (high mobility group box 1), HSP (heat shock protein) and oxidized DNA. The NF-KB is an essential protagonist in the interaction between tissue injury, cell death and inflammatory response to ionizing radiation [7].

\section{New theories, bystander effect or spectator effect}

A recent and fascinating theory about damage by ionizing radiation is called bystander effect. This theory explains that the damage caused by ionizing radiation can occur due to the radiation's direct effect, generation of intracellular signaling, cytokines and oxygen free radicals production and inflammatory response. In the bystander effect, the affected cells by radiation are not directly exposed to radiation and can be far from the exposure focus [8].

A study performed in the body of rats exposed to ionizing radiation but protected with leaded elements in their neck and head; the presence of the bystander effect in the cerebellum was demonstrated through the finding in the mentioned organ of rupture doublestranded DNA and cell death by apoptosis [9].

\section{Interventional cardiology diseases related to ionizing radiation}

To fully comprehend neoplasia in interventional radiology in relation to ionizing radiation exposure the technical aspect of the catheterization labs has to be taken into account. The operator is located to the right of the patient with the radiation source to the left, this means his left hemibody is closest to the source and the operator's right hemibody is farther away. This explains why most brain tumors and ocular pathology are left-sided and a minority right-sided. One of the explanations for the right-sided lesions might be the bystander effect, nonetheless, there are still missing theories and investigations to discover and solve questions still existing in this topic.

Annual exposition to ionizing radiation on the left side is on average $20-30 \mathrm{mSv}$, which corresponds to 10 times the annual dose to the whole body. Also, the left side has 2 times more exposure than the right side [10].

\section{Cerebral Neoplasia}

In a recent publication, Roguin talks about 31 physicians chronically exposed to ionizing radiation who developed malignant brain tumors. Among them, 23 were interventional cardiologists, 2 electrophysiologists and 6 interventional radiologists. All of them had had chronic exposure to ionizing radiation (between 12 to 32 years). Among the most frequent tumors were: 17 cases $(55 \%)$ of multiform glioblastoma, 2 cases (7\%) of astrocytoma, and 5 cases (16\%) of meningioma, in the most of the cases $85 \%$ (22 patients) the tumor localization was left sided, 3 cases in the right side and 1 case in the midline (Table 1) [10].

\section{Ocular Disease}

Exposure to ionizing radiation is associated with the development of crystalline opacification and cataracts. The most frequent type of cataracts associated to 


\begin{tabular}{|c|c|c|c|c|c|c|c|c|c|c|c|}
\hline & Country & $\begin{array}{c}\text { Year } \\
\text { Diagnosed }\end{array}$ & $\begin{array}{c}\text { Age at } \\
\text { Diagnosis } \\
\text { (yrs) }\end{array}$ & Gender & $\begin{array}{c}\text { Radiation } \\
\text { Exposure } \\
\text { (Latency } \\
\text { Period) } \\
\text { (yrs) }\end{array}$ & Tumor Type & $\begin{array}{c}\text { Side } \\
\text { Involved }\end{array}$ & Occupation & Prognosis & $\begin{array}{c}\text { Age at } \\
\text { Death } \\
\text { (yrs) }\end{array}$ & $\begin{array}{l}\text { Survival } \\
\text { After } \\
\text { Diagnosis }\end{array}$ \\
\hline 1 & $\begin{array}{l}\text { Toronto, } \\
\text { Canada }\end{array}$ & 1997 & 62 & M & 20 & GBM & Left side & IC & $\begin{array}{c}\text { Died in } \\
1999\end{array}$ & 64 & 2 years \\
\hline 2 & Toronto & 1997 & 53 & M & 20 & GBM & Left side & IC & $\begin{array}{c}\text { Died in } \\
1999 \\
\end{array}$ & 55 & 4 years \\
\hline 3 & Haifa, Israel & 1998 & 48 & M & 12 & Meningioma & $\begin{array}{c}\text { Left } \\
\text { temporal }\end{array}$ & IC & Alive & & \\
\hline 4 & Paris, France & 2001 & 56 & M & 25 & GBM & $\begin{array}{l}\text { Left } \\
\text { temporal }\end{array}$ & IC & $\begin{array}{l}\text { Died in } \\
2005\end{array}$ & 59 & 4 years \\
\hline 5 & Paris, France & 2005 & 49 & M & 22 & GBM & $\begin{array}{c}\text { Left } \\
\text { temporal, } \\
\text { occipital }\end{array}$ & IC & $\begin{array}{l}\text { Died in } \\
2006\end{array}$ & 50 & 16 months \\
\hline 6 & Haifa, Israel & 2009 & 62 & M & 32 & GBM & Left frontal & IC & $\begin{array}{l}\text { Died in } \\
2010\end{array}$ & 63 & 11 months \\
\hline 7 & Sweden & NA & & $\mathrm{M}$ & 20 & Acoustic neurinoma & NA & IR & & & \\
\hline 8 & Sweden & NA & & $M$ & 28 & Meningioma & NA & IR & & & \\
\hline 9 & Sweden & NA & & M & 31 & Oligodendroglioma & NA & IR & & & \\
\hline 10 & London, UK & 2009 & 62 & $\mathrm{M}$ & 27 & Parotids & Left & IC & & & \\
\hline 11 & $\begin{array}{c}\text { Zürich, } \\
\text { Switzerland }\end{array}$ & 2009 & 53 & $M$ & 20 & GBM & Left frontal & Pediatric EP & $\begin{array}{l}\text { Died in } \\
2010\end{array}$ & 54 & 14 months \\
\hline 12 & Virginia & 2009 & 67 & $M$ & 29 & GBM & Left & EP & Alive & & \\
\hline 13 & $\begin{array}{l}\text { Dundee, } \\
\text { Scotland }\end{array}$ & 2007 & 59 & M & 29 & Astrocytoma & Left & IC & $\begin{array}{c}\text { Died in } \\
2009\end{array}$ & 61 & 2 years \\
\hline 14 & Kentucky & 2008 & 54 & $M$ & 22 & GBM & Left & IC & $\begin{array}{l}\text { Died in } \\
2010\end{array}$ & 56 & 2 years \\
\hline 15 & Illinois & 2003 & 65 & $M$ & 32 & GBM & Midline & IC & $\begin{array}{l}\text { Died in } \\
2007\end{array}$ & 67 & 2 years \\
\hline 16 & $\begin{array}{l}\text { Gainesville, } \\
\text { Florida }\end{array}$ & $1990 \mathrm{~s}$ & $\sim 40$ & $M$ & $\sim 10$ & GBM & $\begin{array}{c}\text { Left } \\
\text { occipital } \\
\text { lobe }\end{array}$ & IC & & NA & \\
\hline 17 & $\begin{array}{l}\text { West of } \\
\text { Scotland }\end{array}$ & 2008 & 52 & Female & NA & GBM & Left frontal & Radiologist & $\begin{array}{c}\text { Died in } \\
2009\end{array}$ & 53 & 1 year \\
\hline 18 & $\begin{array}{l}\text { West of } \\
\text { Scotland }\end{array}$ & 2011 & NA & $M$ & NA & GBM & $\begin{array}{c}\text { Left } \\
\text { temporal }\end{array}$ & IR & Alive & & \\
\hline 19 & $\begin{array}{l}\text { Leipzig, } \\
\text { Germany }\end{array}$ & 2005 & 55 & $M$ & 20 & GBM & Right & IC & & 56 & 1 year \\
\hline 20 & $\begin{array}{l}\text { Homburg, } \\
\text { Germany }\end{array}$ & 2010 & 54 & $M$ & 25 & $\begin{array}{l}\text { Astrocytoma (grade } \\
\text { III) }\end{array}$ & Left & IC & Alive & & \\
\hline 21 & $\begin{array}{l}\text { Linköping, } \\
\text { Sweden }\end{array}$ & 2009 & 49 & $M$ & 12 & GBM & $\begin{array}{l}\text { Left frontal } \\
\text { lobe }\end{array}$ & IC & $\begin{array}{l}\text { Died in } \\
2011\end{array}$ & 49 & 2 years \\
\hline 22 & $\begin{array}{c}\text { Santa } \\
\text { Monica, } \\
\text { California }\end{array}$ & 2006 & 52 & $M$ & 21 & GBM & Left & IC & Died n 2007 & 53 & 2 years \\
\hline 23 & California & 2008 & 71 & M & 22 & Glioma & $\begin{array}{c}\text { Left } \\
\text { temporal }\end{array}$ & IC & Alive & & \\
\hline 24 & Maryland & 2012 & 57 & $\mathrm{M}$ & 26 & Meningioma & Right & IR & Alive & & \\
\hline 25 & Belgium & $1990 \mathrm{~s}$ & NA & $M$ & NA & GBM & NA & IC & Died & NA & \\
\hline 26 & Belgium & $1990 \mathrm{~s}$ & NA & $M$ & NA & GBM & NA & IC & Died & & \\
\hline 27 & Ireland & 2011 & 55 & $M$ & 31 & Neck Lymphoma & Left & IC & Alive & & \\
\hline 28 & Israel & 2012 & 62 & M & 32 & Parotids & Right & IC & Alive & & \\
\hline 29 & Germany & 2003 & 49 & $\mathrm{M}$ & 19 & Meningioma & Left & IC & Alive & & \\
\hline 30 & Middle East & 2009 & 62 & $M$ & 30 & Meningioma & Left & IC & Alive & & \\
\hline 31 & Middel East & 2009 & 52 & $M$ & 19 & Tonsillar tumor & Left & IC & Alive & & \\
\hline
\end{tabular}


radiation is the subcapsular posterior type [11].

Some of the causes why ocular disease is common in interventional cardiologist are: direct exposure to radiation, and an ocular dose per procedure of $165 \mu \mathrm{Sv}$ which can decrease with the use of leaded glasses to $37 \mu \mathrm{Sv}$. Interventional cardiologists have low rates of usage of ocular protection devices. Previously, the limit for ocular radiation was very high; on April 21, 2011 the ICRP (International Commission on Radiological Protection) drastically decreased the allowed levels of ocular radiation from $150 \mathrm{mSv}$ to $20 \mathrm{mSv}$ per year [12].

A cross sectional study [13] done during an interventional cardiology conference compared occupationally exposed to ionized radiation people versus non-exposed people. The participants filled out a survey which evaluated risk factors and eliminate confounding factors and the ones included were performed an ophthalmological exam with a slit lamp. 117 participants were included, from which 99 (85\%, $49 \pm 11$ years old, $82 \%$ males) had a risk factor and 18 (15\%, $39 \pm 12$ years old, $61 \%$ males) were not exposed. Presence of crystalline changes (cortical, posterior, subcapsular) including subclinical anomalies was higher in the exposed population ( 47 vs. 17\%, $\mathrm{p}=0.015$ ).

\section{Thyroid Neoplasia}

Ionizing radiation induced DNA damage, directly or through the production of reactive oxygen substances. Thyroid tissue contains high quantity of NADPH oxidase, these are the enzymes specialized in the production if reactive oxygen substances, also known as NOX/DUOX. When exposed to radiation the expression on DUOX1 increases, causing an important rise of reactive oxygen substances in the thyroid gland after radiation exposure. This could explain its high sensitivity to radiation. This DNA injury includes single and double-stranded DNA ruptures, which lead to deletions and chromosomal rearrangement.

There is a significantly high risk when the radiation doses id 50-100 mGy and increases as the radiation to the thyroid gland increases.
One third of thyroid tumors which appear after radiation exposure are malignant, most commonly papillary thyroid carcinoma. Papillary thyroid carcinoma occurs at least 5 to 10 years posterior to the radiation exposure and may even occur after decades of the exposure [14].

\section{Cutaneous Neoplasia}

For years interventional cardiologists have believed they are protected against ionizing radiation, which disperses during the procedures. Unfortunately, skin on the head, upper extremities and part of the lower extremities are unprotected during these procedures and may receive very high dose of radiation during complicated procedures which have a longer duration.

Basal cell carcinoma is the most common type of skin carcinoma in people exposed to ionizing radiation. There is a higher risk in people with blonde hair and lighter skin. This type of cancer may recur but may not metastasize and the complications are associated with tissue destruction and disfiguration in the affected and nearby tissue [15].

Other lesions found associated with radiation are keratotic lesions, squamous cell carcinoma, and carcinoma in situ, but as stated previously, the most frequent is basal cell carcinoma [16].

\section{Hematologic neoplasia}

Like most neoplastic pathologies (except cerebral) there is not enough data of physicians exposed to ionizing radiation, which allows talking about this topic. A Spanish study [17] talks about the risk of development of either leukemia or skin cancer in interventional radiologist measured at 2.18/1000 people/year. Other predictive risk values in these professionals can be seen in Table 2.

Due to the lack of information and data in health professionals (due to the long time required developing the disease), most of the data is obtained from the clinical findings in populations exposed chronically to radiation, such as nuclear accident victims (eg.

Table 2. Risk developing solid and non-solid tumors

\begin{tabular}{|cccc|} 
& Cancer Type & \multicolumn{2}{c|}{ Excess absolute risk (EAR) $\left(\mathbf{1 0}^{-\mathbf{4}}\right.$ per PY Sv) } \\
\cline { 2 - 4 } & & Male & Female \\
\hline Solid cancer & Non-melanoma skin cancer & $0.38[0.0,1.1]$ & $0.32[0.0,0.11]$ \\
\hline \multirow{3}{*}{$\begin{array}{c}\text { Non-solid } \\
\text { cancer }\end{array}$} & Leukemia & $4.14[3.06 .5 .39]$ & $2.41[1.71,3.23]$ \\
\cline { 2 - 4 } & Hodgkin's disease & $0.04[0.01,0.3]$ & $0.04[0.01,0.3]$ \\
\cline { 2 - 4 } & Non-Hodgkin's lymphoma & $0.46[0.04,1.16]$ & $0.0[<0,0.28]$ \\
\cline { 2 - 4 } & Multiple mieloma & $0.26[<0,0.4]$ & $0.08[<0,0.4]$ \\
\hline
\end{tabular}




\begin{tabular}{|c|c|c|c|}
\hline & Deaths & ERR per Gy & $90 \% \mathrm{Cl}$ \\
\hline Leukaemia excluding CLL* & 531 & 2.96 & $1 \cdot 17$ to $5 \cdot 21$ \\
\hline Chronic myeloid leukaemia* & 100 & $10 \cdot 45$ & 4.48 to 19.65 \\
\hline Acute myeloid leukaemia* & 254 & 1.29 & -0.82 to 4.28 \\
\hline Acute lymphoblastic leukaemia* & 30 & $5 \cdot 80$ & NE to 31.57 \\
\hline $\mathrm{CLL}^{*}$ & 138 & -1.06 & NE to 1.81 \\
\hline Multiple myeloma† & 293 & 0.84 & -0.96 to 3.33 \\
\hline Non-Hodgkin lymphomat & 710 & 0.47 & -0.76 to 2.03 \\
\hline Hodgkin's lymphoma† & 104 & $2 \cdot 94$ & NE to 11.49 \\
\hline
\end{tabular}

***CLL $=$ Chronic lymphoid leukemia

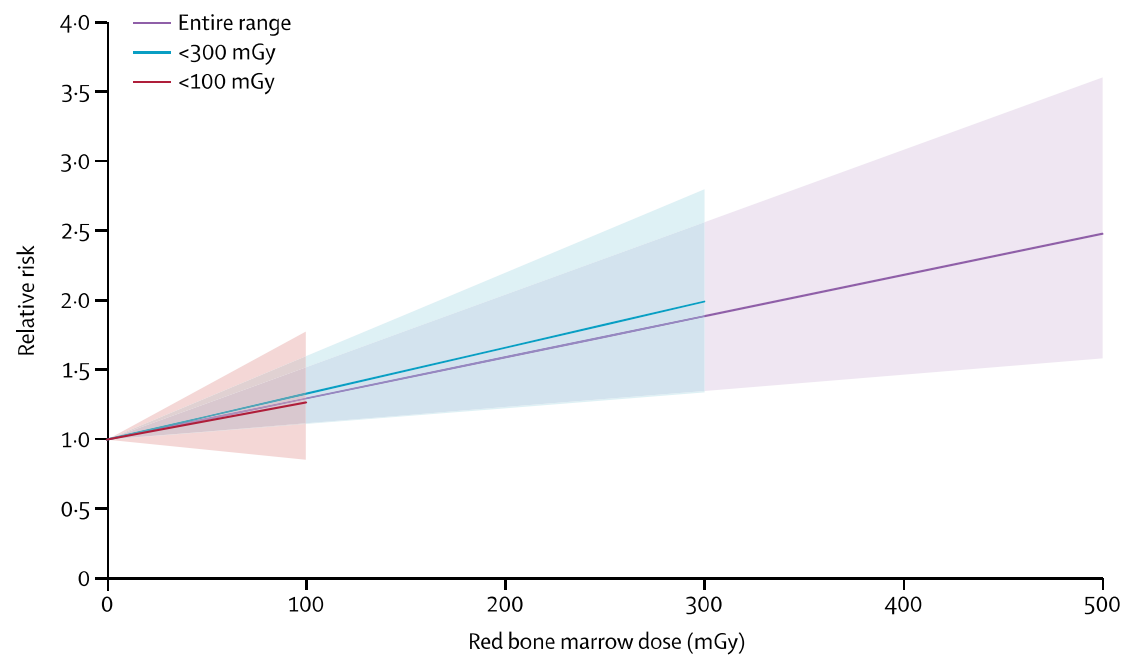

Figure 1. Risk of development of leukemia (including $\mathrm{CLL}$ ) in relation with accumulated bone marrow radiation

Chernobyl), atomic bomb survivors and nuclear power plant workers.

In these populations the most frequent type of leukemia is myeloid. The number of deaths according to the different types of leukemia and lymphomas in relationship to the cumulative radiation [18] dose can be seen in Table 3. In Figure 1, is depicted the risk of developing leukemia (excluding chronic lymphocytic leukemia) in relation with the cumulative radiation dose in the bone marrow.

\section{Conclusions}

Ionizing radiation represents a damaging agent

\section{References}

1. Zivile V, Martynas J, Inga C. Ionizing radiation exposure in interventional cardiology: current radiation protection practice of invasive cardiology operators in Lithuania. J Radiol Prot. 36: 695-708 (2016).

2. Roguin A, Goldstein J, Bar O, et al. Brain and neck tumors among physicians performing interventional procedures. $\mathrm{Am} \mathrm{J}$ Cardiol. 111: 1368-1372 (2013).

3. Lomax M, Folkes L, O'Neill P. Biological consequences of with the capacity to produce long term severe lesions in the chronically exposed personnel: interventional cardiologist, technicians, interventional cardiology nurses, electrophysiologist and interventional radiologists. These professionals should have more awareness about this risk, but also the regulatory institutions and the academic entities should implement strategies to decrease the unnecessary radiation exposure and apply politics to actively protect the personnel. Worldwide there is lack of research on this topic and there is an important under registration about the real cause, which may aid in the implementation of protective and preventive measurements.

radiation-induced DNA damage: relevance to radiotherapy. Clin Oncol. 25(10): 578-585 (2013).

4. Ermakov A, Konkova M, Kostyuk S, et al. Oxidized extracellular DNA as a stress signal in human cells. Oxid Med Cell Longev. 2013: 649747 (2013).

5. Allam R, Lawlor KE, Yu ECW, et al. Mitochondrial apoptosis is dispensable for NLRP3 inflammasome activation but nonapoptotic caspase- 8 is required for inflammasome priming. EMBO Rep. 15(9): 982-990 (2014). 
6. Bogdan C. Nitric oxide synthase in innate and adaptive immunity: an update. Trends Immunol. 36(3): 161-178 (2015).

7. Piccinini A, Midwood K. DAMPening inflammation by modulating TLR signalling. Mediators Inflamm. 2010: 672395 (2010).

8. Lorimore S, Coates P, Wright E. Radiation-induced genomic instability and bystander effect: inter-related nontargeted effects of exposure to ionizing radiation. Oncogene. 22(45): 7058-7069 (2003).

9. Mancuso M, Pasquali E, Leonardi S, et al. Oncogenic bystander radiation effects in Patched heterozygous mouse cerebellum. Proc Natl Acad Sci USA. 105(34): 12445-50 (2008).

10. Roguin A, Goldstein J, Bar Olivier, et al. Brain and neck tumors among physicians performing interventional procedures. $\mathrm{Am} J$ Cardiol. 111: 1368-1372 (2013).

11. Picano E, Vano E, Domenici L, et al. Cancer and non-cancer brain and eye effects of chronic low-dose ionizing radiation exposure. BMC cancer. 12:157 (2012).

12. ICRP statement on tissue reactions: Approved by the commission on April 21, 2011. International Commission on Radiological Protection. (2011)
13. Karatasakis A, Brilakis H, Danek B, et al. Radiation-associated lens changes in the cardiac catheterization laboratory: Results from the IC-CATARACT (CATaracts Attributed to RAdiation in the CaTh lab) study. Catheter Cardiovasc Interv. 91(4): 647-654 (2018).

14. Iglesias $\mathrm{M}$, Schmidt $\mathrm{A}$, Ghuzlan $\mathrm{A}$, et al. Radiation exposure and thyroid cancer: a review. Arch Endocrinol Metab. 61(2): 180-7 (2017).

15. Eagan J, Jones C. Cutaneous cancers in an interventional cardiologist: a cautionary tale. J Interv Cardiol. 24(1): 49-55 (2011).

16. Hashizume S, Otani K, Serikawa K, et al. Radiation-induced malignant skin tumors in the hands of five doctors. Gan No Rinsho. 36(2): 224-228 (1990).

17. Ramos M, Montoro A, Almonacid M, et al. Radiation effects analysis in a group of interventional radiologists using biological and physical dosimetry methods. Eur J Radiol. 75(2): 259-64 (2015).

18. Leuraud $\mathrm{K}$, Richardson $\mathrm{D}$, Cardis $\mathrm{E}$, et al. Ionising radiation and risk of death from leukemia and lymphoma in radiationmonitored workers (INWORKS): an international cohort study. Lancet Haematol. 2(7): e276-81 (2015). 